\title{
ONE STEP CLOSER TO CITY BRANDING THROUGH CULTURE: CONSUMER PREFERENCES FOR CULTURAL TOURISM SERVICES IN ALBA IULIA - CUSTOMIZATION ON NATIONAL MUSEUM OF UNIFICATION
}

\author{
Larisa Loredana Dragolea ${ }^{1}$ \\ Denisa Adriana Cotîrlea ${ }^{2}$
}

\begin{abstract}
This paper approaches aspects regarding consumer preferences for cultural tourism services and museum tours. The objectives of the current study aim to know the current interest for different types of tourism, to determine the visiting frequency of the National Museum of Unification by Romanian tourists, to identify the positive and negative aspects noticed by tourists during their visit at the National Museum of Unification and to identify the activities that should be organized by this museum across the year, in order to increase the tourist flows, comparing to the tourist flows of previous years.
\end{abstract}

Key words: cultural tourism, services, consumer, marketing;

JEL codes: M31, M30, Z19

\section{Introduction}

The geopolitical context and, implicitly, the current geocultural context require a redefinition - or a more complex circumscription - of the "national culture" concept. In terms of the question "What is cultural marketing?", one of the briefest answers would be "the application of marketing strategies within a cultural organization". However, in practice, cultural marketing is a field in its own right due to the particularities of activities run by cultural organizations. It should be mentioned that in the case of cultural marketing, efficiency is not measured primarily in economic terms, but rather in terms of availability and ability of the organization to fulfil its mission, to develop relationships and to meet its objectives.

This subject was addressed because cultural marketing, although circulated as a concept, is not applied properly in practice due largely to the fact that it doesn't receive the adequate importance within managerial strategies. Also, it needs to be mentioned that there is a lack of specialized and dedicated people: there is a shortage of experts in cultural marketing because it is a specialized niche, on the border between marketing and culture. Because the authors of this article believe cultural marketing represents an important pawn in nation branding, it was decided to customize consumer preferences for tourism services related to the National Museum of Unification - which is one of the important vectors of nation branding through culture.

In this paper, the authors aimed to highlight the characteristics of consumer behaviour in the context of cultural tourism, in general, and in the context of museum services (the National Museum of Unification in Alba Iulia), in particular. It was attempted to shape the framework regarding the market in which the museum operates, to conduct a brief analysis regarding demand and supply, as well as to identify the necessary elements for the case study.

\footnotetext{
1 „1 Decembrie 1918” University of Alba Iulia, Romania, e-mail: larisadragolea@yahoo.com.

2 "Babes-Bolyai" University of Cluj Napoca, e-mail: cotirlea.denisa@ yahoo.com.
} 
The case study focuses on general aspects regarding the consumer preferences for tourism services in general, as well as aspects related to consumer preferences for cultural tourism and museum services. The objectives of the current study aim to know the current interest for different types of tourism, to determine the visiting frequency of the National Museum of Unification by Romanian tourists, to identify the positive and negative aspects noticed by tourist during their visit at the National Museum of Unification and to identify the activities that should be organized by this museum across the year.

\section{Issues concerning city branding through culture and several approaches regarding cultural marketing and consumer behaviour characteristics related to museum services}

The process of branding helps a city to define its identity, to promote itself, to draw attention and to differentiate from others. For a city to reach to have a strong brand, there are needed inhabitants who desire this thing; generally speaking, behind building city brand stay ambitious and visionary management bodies that perceive branding process as a strategic economic necessity. A city can be promoted in several ways: as a tourist destination, as a trade or business center, as a quiet and safe place etc. It is thus necessary to identify the key attributes and strengths; other elements that can be taken into account target quality of life, unaltered nature, the open and tolerant spirit of the people etc.

Local brand construction is based on clear, simple and differentiated proposals, often built around several emotional qualities that can be easily symbolized verbally and visually. In this context, is needed to delimitate the sense of several notions that surround nation branding process.

Considering that culture strengthens a city's identity, essential for place/destination branding are two elements that connect the city itself to culture: first that should be mentioned is "the importance of the image of the city for city branding and its power to influence even the shaping of the city itself" and, secondly, "the heavy dependence of the city's brand on the city's identity" (Kavaratzis, 2005).

As cities have to re-imagine a new environment, culture becomes today one of the most added value. A new famous museum, events, a well-known personage born in the city, a famous sport team, all can be now a subject to be developed to promote the city. Culture is going to be the new gate were creativity, art, music, can come in to promote the new modern city (Tayebi, 2006). In this context, "[...] museums are having aggressively market themselves and license their collections, histories and buildings as a brand" (Cummings and Lewandowska in Graeme, 2003)

In Romania, cultural marketing studies are (relatively) limited and focused mainly on researching the needs and consumption of culture. Just as insignificant are the concerns related to implementing marketing methods in the field of culture, which, as a matter of fact, is at the origin of desires and personal behaviour, being the determining factor of an individual's aspirations and conducts. Cultural awareness involves perceiving the originality of a work of art, the invested sensitivity, the strength of ideas, and the exemplarity of the proposed models.

Affirming marketing in the field of culture requires combining the concept of marketing with the concept of culture, creating new concepts and enriching the existing ones with meanings suggested by cultural practice, experimenting new investigating methods for cultural consumption and consumer behaviour, developing efficient methods for predicting cultural phenomena, etc. Implementing marketing in the field of culture involves researching the cultural market, identifying the needs, aspirations and expectations of consumers - combined with creating new needs at the level of new market segments - assessing the quality and size of the supply, blending it with the consumption demands of the population, determining consumer satisfaction, motivations and cultural behaviours, etc.

The consumptions of individuals, micro-groups or larger groups are axes that experts take into account when it comes to marketing research in the field of museums. The consumption of culture is done differently due to several factors: income level, occupation, living environment, 
family size. Knowing the relationship between needs and consumption, as well as the relationship between different needs is necessary for conducting more efficient marketing activities.

Researching the consumption of museum services requires studying consumer behaviour first, which is determined by all decisions and acts that are aimed at exploiting opportunities for obtaining and using museum products and services. The behaviour of museum consumers has an explicit dimension, accessible for quantification and observation, but it also has a more subtle and complex dimension, which includes the behavioural response to the cultural supply. Consumer behaviour includes three major phases: pre-purchase, purchase, post-purchase. Literature mentions that this type of behaviour is determined by factors such as need arousal, information search, analysis of alternatives, purchasing and using goods and services, assessing satisfaction/dissatisfaction in relation to cultural needs.

The studies dedicated to cultural consumption emphasis the internal causes of consumer behaviour, but also their motivation. Certain more general needs concern culture as a whole (for example, the studies of Renè Kaēs showed that going to theather plays, visiting art exhibits, etc., was motivated by the aspiration to develop personality in a harmounious manner), other needs can be placed on the third or fourth layer of the Maslow pyramid, namely self-affirmation, self-esteem and creativity. The researchers of cultural consumption concluded that cultural habits of individuals are as important as financial resources. Habits are behavioural customs characterized by repeatability and are distributed according to education, age, personality, occupation and experience, and the structure and features of the cultural market. There are certain factors that influence the availability of individuals for a certain type of cultural consumption, such as: age, the demands of community life, occupation, free time, family status. Knowing these habits is important in achieving the marketing mix strategies to obtain maximum efficiency (Table 1).

When habits achieve certain constancy, they become consumer habits. A. Morales believed that there is a classification of individuals according to their own pattern of daily life, in the context of which cultural consumption habits are inserted (Morales A., 1974: 12).

Motivation, habits and consumer patterns create certain inclinations for acting on the cultural market, certain attitudes towards products. If attitudes can be studied using scales and projective tests, consumer motivation - as consumer habits - is researched by using the methods of observation and investigation.

Table no. 1 .

\section{Model of purchasing behaviour}

\begin{tabular}{|c|c|c|c|c|c|c|}
\hline $\begin{array}{c}\text { Marketing } \\
\text { stimuli }\end{array}$ & Other stimuli & & Buyer features & Decision-making & & $\begin{array}{c}\text { Decisions } \\
\text { of buyer }\end{array}$ \\
\hline $\begin{array}{l}\text { Product } \\
\text { Price } \\
\text { Location } \\
\text { (place) } \\
\text { Advertising }\end{array}$ & $\begin{array}{c}\text { Economic } \\
\text { Technological } \\
\text { Political } \\
\text { Cultural }\end{array}$ & $\rightarrow$ & $\begin{array}{l}\text { - Cultural } \\
\text { - Social } \\
\text { - Personal } \\
\text { - Psychological }\end{array}$ & $\begin{array}{l}\text { - Recognition } \\
\text { of the problem } \\
\text { - Searching for } \\
\text { information } \\
\text { - Evaluation of } \\
\text { alternatives } \\
\text { - Purchasing } \\
\text { decision } \\
\text { - Post-purchase } \\
\text { behaviour }\end{array}$ & $\rightarrow$ & $\begin{array}{l}\text { Choosing: } \\
\text { - product } \\
\text { - brand } \\
\text { - supplier } \\
\text { - time of } \\
\text { purchase } \\
\text { - quantity }\end{array}$ \\
\hline
\end{tabular}

(Source: Kotler P., 2000: 224)

As regards to the present study, the authors have chosen a case study about consumer preferences for museum services in the context of cultural tourism, conducting an investigation among people who visited the National Museum of Unification in Alba Iulia in the last five years. 
Consumer behaviour is influenced by cultural, social and psychological factors, highlighted in table no. 2.

That being said, it is found that individuals don't meet their needs randomly, but they rank them. Thus, ranking consumer preferences takes into account developing consumption programs from which the consumer expects a certain aggregated satisfaction, which is determined by considering socio-professional factors, mental features of the person, needs' awareness, market exploration, analysis of alternatives, purchasing and using goods and services, assessing satisfaction or dissatisfaction in terms of cultural needs, individual habits, tastes and preferences, advertising, opinion polls, etc.

Table no. 2 .

Factors influencing consumer behaviour

\begin{tabular}{|c|c|c|c|c|}
\hline Cultural & Social & Personal & Psychological & \\
\hline $\begin{array}{l}\text { - Culture } \\
\text { - Cultural } \\
\text { subsystem } \\
\text { - Social class }\end{array}$ & $\begin{array}{l}\text { - Affiliation } \\
\text { groups } \\
\text { - Family } \\
\text { - Social role and } \\
\text { status }\end{array}$ & $\begin{array}{l}\text { - Age and stage of } \\
\text { life cycle } \\
\text { - Occupation } \\
\text { - Financial situation } \\
\text { - Lifestyle } \\
\text { - Personality and } \\
\text { self-opinion }\end{array}$ & $\begin{array}{l}\text { - Motivation } \\
\text { - Perception } \\
\text { - Learning } \\
\text { - Beliefs and } \\
\text { skills }\end{array}$ & Buyer \\
\hline
\end{tabular}

Case study

(Source: Kotler, P. Et. al., 1998)

\section{Methodology}

The method used for selective research of the community was the survey-based investigation because it provides relevant data about the characteristics of tourism demand in a given period (namely during the period if the investigation). Among the most important advantages of surveys are the short time needed to conduct this type of research and they are relatively inexpensive; also, there is expert opinion that the results obtained through selective research are much more relevant than those resulting from total observation.

Thus, from November $1^{\text {st }}$ to December $1^{\text {st }} 2010$, a questionnaire regarding consumer preferences for services provided by the National Museum of Unification in Alba Iulia was applied on a sample of 416 persons, who, moreover, were perceived as consumers of cultural tourism services. It should be mentioned the researchers took into account the answers of the respondents who visited the museum in question in the last five years, the final size of the sample being 385 people (for 31 of them, the time elapsed since the last visit had exceeded the limit of 5 years). This time span was chosen because the museum in question didn't suffer any significant changes in terms of permanent exhibits, involved human resources, existing exhibits, etc. For financial and time reasons, we couldn't increase the size of the sample in order to reduce selection error, which is why the maximum permissible error of $\pm 5 \%$ was the target of the study in order to ensure representativeness.

In the context of the study, the unit of observation is represented by: for the study;

- Tourists - who visited the National Museum of Unification within the period allocated

- The students attending "1 Decembrie 1918" University Alba Iulia, who visited the National Museum of Unification between 2006 and 2010;

- The students attending "Dionisie Pop Martian" Economic College in Alba Iulia, who visited the National Museum of Unification between 2006 and 2010;

- Internet users residing in Romania, who have visited the National Museum of Unification in Alba Iulia in the last five years. 
The questionnaire was divided into four parts, each being aimed at defining elements necessary for the subsequent correlations between the profile of the consumer of cultural tourism services, age and area of origin, income and education level, mean of transport used to reach the place of consumption and any other variable in the present study. Thus, the first part of the questionnaire includes five general questions, while the second part has 18 questions that are mainly about the attitude of the respondent towards the museum and the visiting frequency. The third part includes six questions regarding the respondent's suggestions for the activities run by the National Museum of Unification in Alba Iulia, providing the respondent with the opportunity to answer openly, freely. The last part of the questionnaire consists of eight questions regarding the respondents' personal information. Therefore, the questionnaire has 38 questions with mixed, multiple answers. For an easier interpretation of data, the results expressed as percentage were rounded.

\section{Interpretation of results}

In terms of the type of practiced tourism, most respondents prefer leisure tourism, followed by those who prefer cultural/religious tourism, sports tourism and shopping tourism (Figure 1). Most respondents - a percentage of $60 \%$ - claim they visit museums regardless of their profile, followed by those who prefer art museums and those who prefer natural science museums and memorials; at the opposite end are respondents who prefer museums of ethnography (Figure 2).

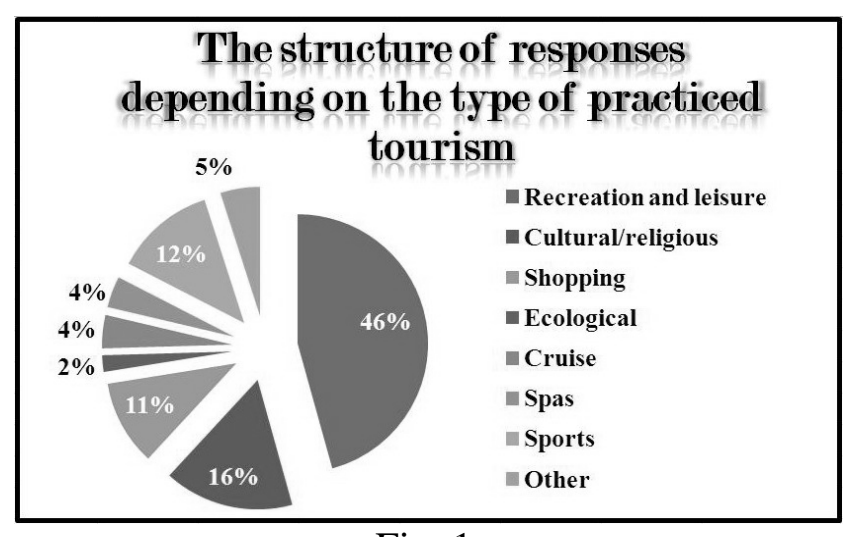

Fig. 1

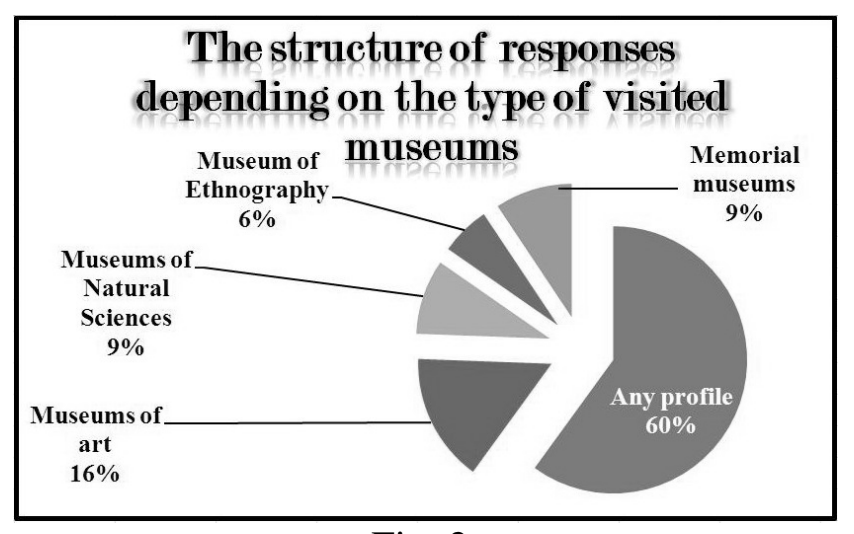

Fig. 2

In most cases (43\% of total surveyed), respondents prefer to visit a museum with friends, followed by those who prefer to visit museums in organized groups. In terms of visiting the whole museum or only an exhibit, most respondents (73\%) visit the entire museum, while $12 \%$ choose to visit temporary exhibits (Figure 3). In regard to the preferred guiding, most respondents (49\%) like full guiding, followed by those who prefer to read the exhibits' labels (23\%); at the opposite end are people who prefer booklets about the museum's exhibits (16\%) and people who do not wish to receive any guidance during the visit $(12 \%)$.

Most respondents have visited the National Museum of Unification in the last year $(46 \%)$, followed by those who visit the museum once every three years $(31 \%)$ and the respondents who stated that 3 to 5 years have passed since their last visit (23\%) (Figure 4). 


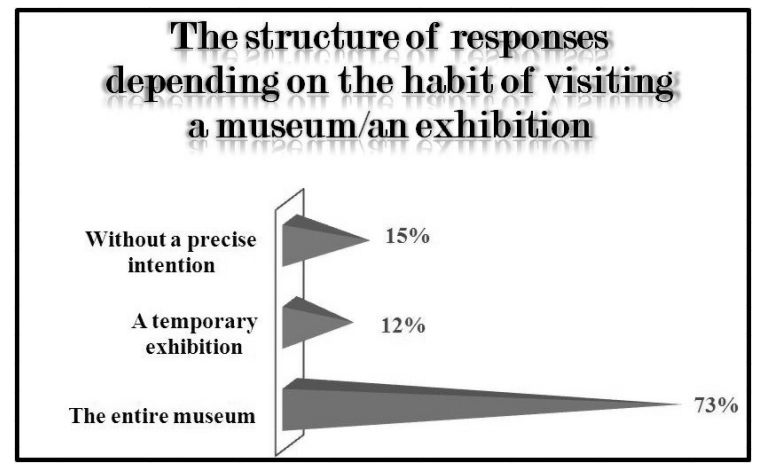

Fig. 3

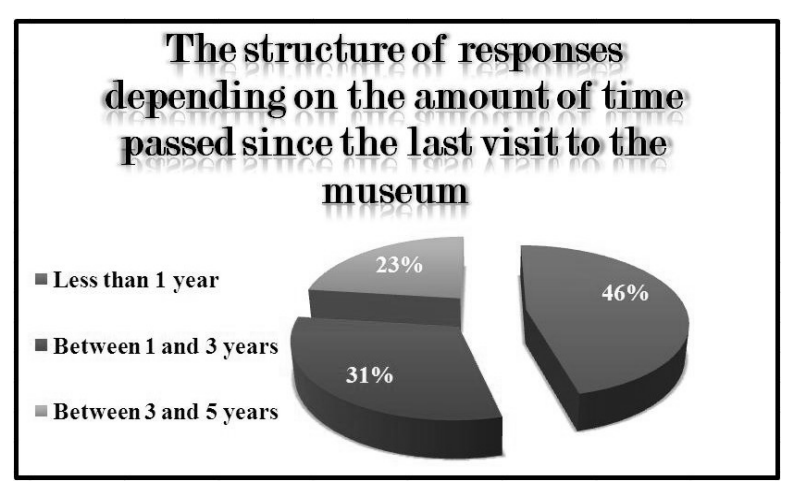

Fig. 4

In terms of the motivation behind visiting this museum, most respondents (56\%) were interested in visiting it, followed by those who were part of an organized trip (31\%); at the opposite end are respondents who visited the National Museum of Unification for other reasons (7\%) and respondents who had nothing better to do with their time (6\%). Most respondents stated they visited the museum for relaxation (51\%), followed by those who visited the museum for professional reasons (31\%). Another category is represented by the visitors who are interested in the activities and exhibits organized by this museum, but want to become informed outside of their profession $(18 \%)$.

The smallest proportion of respondents participated in a regulate manner in activities organized within the museum (6\%), followed by those who took part at exhibits by chance (38\%). In terms of the grade given to the degree of publicity for activities run by the museum, most respondents opted for "satisfying" (38\%) or "very good" (29\%) - Figure 5.

Most respondents $(61 \%)$ believed the information provided by the museum was sufficient, while a rate of $39 \%$ of respondents would have preferred richer and more diverse information. In terms of the manner in which the information was presented, most respondents believed it was done adequately (53\%) or completely adequate (44\%). At the opposite end, 3\% of respondents believed the manner of presentation was not adequate. In regard to the behaviour of the museum staff, it was evaluated as being appropriate by most respondents (62\%) and completely appropriate (35\%); at the opposite end are respondents who believed the staff behaved inappropriately (2\%) and completely inappropriately $(1 \%)$. A rate of $62 \%$ of respondents believed the services provided by the museum met their needs in a significant measure, while $20 \%$ of respondents believed they slightly met their needs.

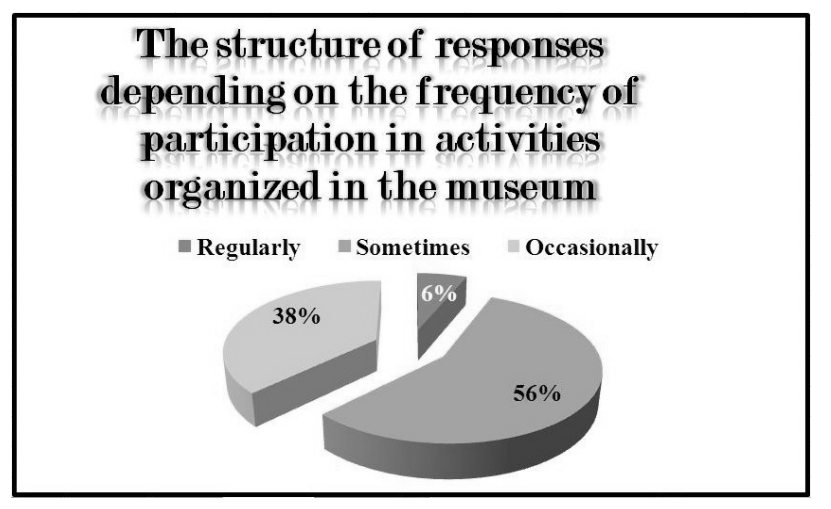

Fig. 5

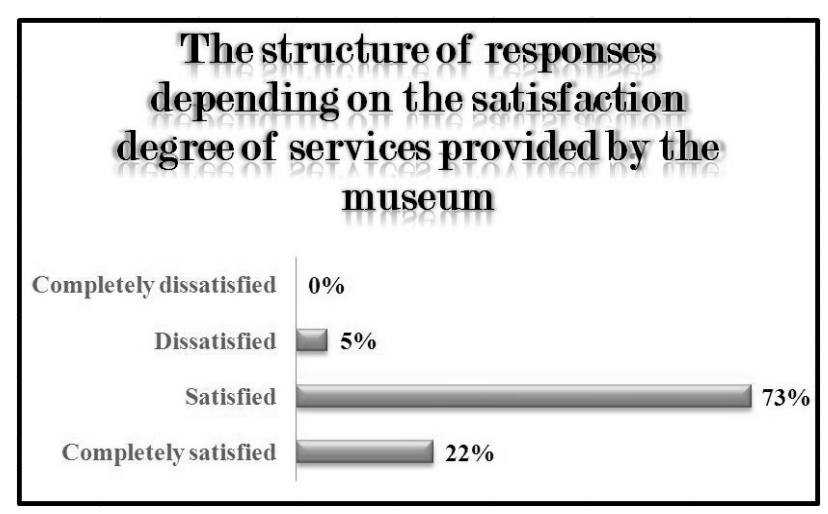

Fig. 6 
The majority of respondents $(73 \%)$ stated they were satisfied by the services provided by the National Museum of Unification (Figure 6) and most respondents believed the price of the admission ticket was adequate. In equal proportions of $46 \%$, respondents stated it's very likely and likely respectively that in the future they will recommend visiting the museum to their acquaintances, while a rate of $7 \%$ of respondents believed it's unlikely.

Regarding the respondents' age, a rate of $80 \%$ was under the age of 25 , followed by those with ages between 26 and 35. Most respondents were female (55\%), while $45 \%$ were male; the vast majority of respondents came from urban areas (95\%) and the rest from rural areas (5\%). In terms of the last graduated school, $44 \%$ of respondents were middle school graduates, $23 \%$ graduated from high-school and $22 \%$ had higher education. $6 \%$ of respondents completed postgraduate studies, 3\% completed vocational schools and equal proportions of $1 \%$ were primary school graduates and post-secondary education graduates.

\section{Conclusions}

Knowing the market requires detailed research, whose results underpin decisions about segmentation, about adapting to consumer needs and more. The lack of market research in the field of culture is largely due to lack of investments. Roxana Crisan, executive director of Act Theatre, identifies one of the main causes of this situation as being "uncultivatedness": (...) I don't refer to not reading books, but to the organisational uncultivatedness. We have no education to invest in culture. Cultural sponsorships are awarded from man to man. We believe the lack of quick advantages is the main reason why investors are running from culture. Organizations managing the national cultural heritage are not sufficiently aware of the need to change how cultural heritage is approached - in the sense of approaching a marketing vision, of implementing marketing techniques and modern management (11). Despite the existing deficiencies in the management of the cultural heritage (by reference to our study) and although most tourists are mainly practicing leisure tourism, they are closely followed by those who prefer cultural and/or religious tourism. Unfortunately, only $6 \%$ of our respondents are regularly participating at the activities organized by the museum, while most respondents don't show a constant interest for them (56\%).

Given that more than half of the questioned persons (51\%) visit the National Museum of Unification in Alba Iulia for relaxation - and not for professional documentation or other concerns outside of their profession - and $52 \%$ of respondents believe the services provided by the museum largely meet their needs, we consider that, in part, the National Museum of Unification in Alba Iulia is operating in accordance to its mission. We believe the high percentage of respondents who declare themselves satisfied with the services provided by the museum (73\%) is in strict accordance with those who consider the price of the admission ticket as being adequate, pointing out the equitable balance between price and quality. At the same time, it could be stated that this is due to the fact tourists - and implicitly, consumers of cultural tourism services - are not sufficiently aware of the need to improve the quality of services provided by cultural organizations and more.

Certainly, the results of the research could be significantly improved, including more nuanced elements about motivation and tourist behaviour, about preferences for various types of tourism, about the real opportunities for the entire population of respondents to practice tourism, etc. This could have been accomplished if the research was aimed at a broader sample, extracted from the entire population who visited the National Museum of Unification. It is certain that the stage of the research and practice in the area of cultural heritage marketing still leaves room for analysis and development. At national level, the situation is completely unsatisfactory, with only a few museums implementing programs aimed at public activity and programs aimed at managing relationships with visitors and the general public. 


\section{References}

1. Cătoiu I., 2002. Cercetări de marketing, Bucharest, Uranus Publishing House

2. Cojocaru V., Mitocaru V., 1998. Pedagogie Muzeală, Bucharest, Center for staff training in cultural institutions

3. Graeme E., 2003. Hard-Branding the Cultural City - From Prado to Prada, available online at http://www.fdcw.unimaas.nl/staff/files/users/405/IJURR.pdf, retrieved on 18 of October, 2012

4. Hudson K., 1979. O istorie socială a muzeelor, Bucharest, Meridiane Uranus Publishing House

5. Kavaratzis M., 2005. Branding the city through Culture and Entertainment, available online at http://aesop2005.scix.net/data/papers/att/378.fullTextPrint.pdf, retrieved on 18 of October, 2012

6. Kotler P., Armstrong G., Saunders J., Wong V., 1998. Principiile Marketingului - ediţie europeană, Bucharest, Teora Publishing House

7. Kotler P., 2000. Management Marketing, Prentince Hall, Inc., Pearson Education Company

8. Mayaux F., 1987. Le marketing au service de la culture, Paris, Revue Francaise du Marketing

9. Morales A., 1974. Sociodinamica culturii, Bucharest, Scientific Publishing House

10. Olteanu V., Cetină I., 1994. Marketingul Serviciilor, Bucharest, Coediţie Marketer Expert

11. Stăncioiu A., 2004. Strategii de marketing în turism, Bucharest. Economic Publishing House

12. Stremțan F., Patriche D., Ispas A., Patriche I., 2000. Elemente de marketing turistic, Deva, Global Media Image Publishing House

13. Tayebi S., 2006. How to design the brand pf contemporary city, available online at http://www.urbanitude.com/citybranding.pdf, retrieved on 18 of October, 2012

14. Zbuchea A., Politici de marketing utilizate în valorificarea patrimoniului cultural național, available online at www.biblioteca.ase.ro/downres.php?tr $=461$, retrieved on $3^{\text {th }}$ of January, 2012

15. *** Studiu de piață în domeniul turismului în județul Alba - 2008, available online at http://www.cjalba.ro/rom/Studiu\%20de\%20piata\%20in\%20domeniul\%20 turismului\%20in\%20judetul\%20Alba\%20-\%20Mai2008.pdf

16. http://coliasmuseo.wordpress.com/tag/marketing-muzeal/

17. http://www.muzeummarketing.com/.

18. www.muzeuluniriialba.ro

19. http://www.citynews.ro/alba/turism-33/turismul-in-judetul-alba-cel-mai-slab-din-regiuneacentru-55486/

20. www.apulum.ro

21. http://www.cjalba.ro/rom/Etapa1.pdf

22. http://www.adrcentru.ro/Document_Files/COMPublicatii/00000666/e9664_Brosura\%20Proi ecte\%20Regio\%20Centru\%20-\%20editia\%20Iunie\%202009.pdf

23. http://www.monitorulab.ro/cms/site/m_ab/news/2006_anul_dezvoltarii_turismului_in_alba_ 6752.html

24. http://www.scritube.com/geografie/turism/DIRECTII-DE-IMBUNATATIRE-SIDE75278.php

25. http://coliasmuseo.wordpress.com/tag/marketing-muzeal/

26. http://www.muzeummarketing.com/

27. http://www.adevarul.ro/locale/alba_iulia/Turisti-Germania-Suedia-MuzeulUnirii_0_411559226.html 